\title{
Advances In Groundwater Remediation: Achieving Effective In Situ Delivery Of Chemical Oxidants And Amendments
}

Siegrist, Robert L.; Crimi, Michelle; McCray, John E.; Broholm, Mette Martina; Bjerg, Poul Løgstrup; Illangasekare, Tissa $\mathrm{H}$.

Publication date:

2011

Document Version

Publisher's PDF, also known as Version of record

Link back to DTU Orbit

Citation (APA):

Siegrist, R. L., Crimi, M., McCray, J. E., Broholm, M. M., Bjerg, P. L., \& Illangasekare, T. H. (2011). Advances In Groundwater Remediation: Achieving Effective In Situ Delivery Of Chemical Oxidants And Amendments. Abstract from NATO Advanced Research Workshop on "Drinking Water Protection by Integrated Management of Contaminated Land", Belgrade, Serbia.

\section{General rights}

Copyright and moral rights for the publications made accessible in the public portal are retained by the authors and/or other copyright owners and it is a condition of accessing publications that users recognise and abide by the legal requirements associated with these rights.

- Users may download and print one copy of any publication from the public portal for the purpose of private study or research.

- You may not further distribute the material or use it for any profit-making activity or commercial gain

- You may freely distribute the URL identifying the publication in the public portal 


\title{
ADVANCES IN GROUNDWATER REMEDIATION: ACHIEVING EFFECTIVE IN SITU DELIVERY OF CHEMICAL OXIDANTS AND AMENDMENTS
}

\author{
Robert L. Siegrist ${ }^{1}$, Michelle Crimi ${ }^{2}$, John E. McCray ${ }^{1}$, Mette M. Broholm ${ }^{3}$, \\ Poul L. Bjerg ${ }^{3}$, Tissa H. Illangasekare ${ }^{1}$ \\ ${ }^{1}$ Colorado School of Mines, Environmental Science and Engineering, Golden, Colorado, 80401 United States \\ ${ }^{2}$ Clarkson University, Institute for a Sustainable Environment, Potsdam, New York 13699 United States \\ ${ }^{3}$ Technical University of Denmark, Department of Environmental Engineering, DK-2800 Kgs. Lyngby, Denmark
}

\begin{abstract}
Contamination of soil and groundwater by organic chemicals represents a major environmental problem in urban areas throughout the United States and other industrialized nations. Over many decades a wide variety of toxic organic chemicals have intentionally or accidentally been released into the subsurface resulting in serious risks to human health and environmental quality (e.g., increased cancer risk through ingestion of contaminated drinking water or inhalation of vapors within buildings).

In situ chemical oxidation (ISCO) has emerged as one of several viable methods for remediation of organically contaminated sites. Many of the most prevalent organic contaminants of concern (COCs) at sites in urban areas (e.g., chlorinated solvents, motor and heating fuels) can be destroyed using oxidants such as catalyzed hydrogen peroxide $\left(\mathrm{H}_{2} \mathrm{O}_{2}\right)$, potassium permanganate $\left(\mathrm{KMnO}_{4}\right)$, sodium persulfate $\left(\mathrm{Na}_{2} \mathrm{~S}_{2} \mathrm{O}_{8}\right)$, and ozone $\left(\mathrm{O}_{3}\right)$. Based on laboratory experimentation, reaction stoichiometries, pathways, and kinetics have been established for many organic COCs. The reactions involve electron transfer or free radical processes with simple to complex pathways following $2^{\text {nd }}$-order kinetics with very fast reaction rates. The need for activation, sensitivity to matrix conditions (e.g., temperature, $\mathrm{pH}$, salinity), and interactions with subsurface properties all vary between the different oxidants and site conditions.

The ISCO systems that can be deployed in the field are highly varied in their features based on site conditions and cleanup goals. Cleanup goals generally specify one or more of the following objectives: 1) reduce the contaminant concentration or mass in a target treatment zone (TTZ) by some percentage (e.g., >90\%), 2) achieve a specified post-ISCO contaminant concentration in a TTZ (e.g., $\leq 1$ $\mathrm{mg} / \mathrm{kg}$ in soil or $\leq 100 \mathrm{ug} / \mathrm{L}$ in groundwater), or 3) achieve a concentration in a groundwater plume at some compliance plane down gradient from a TTZ. To achieve these types of clean up goals, oxidants can be used alone or in combination with other amendments. Oxidant and amendment delivery into the subsurface has most commonly been accomplished using injection wells and probes. While ISCO can be used as a stand-alone remedy, to achieve stringent cleanup goals it is often synergistically combined with other remedies such as in situ bioremediation and monitored natural attenuation.

Effective application of ISCO for remediation of a particular site depends on a clear and thorough understanding of ISCO and its applicability to a given set of contaminant and site conditions to achieve site-specific cleanup goals. A continuing challenge for ISCO, as well as other in situ remediation technologies, is how to achieve in situ delivery and obtain simultaneous contact between oxidants and amendments and the target COCs. During the past few years, advances have been made in several key areas including knowledge and know-how associated with: 1) use of amendments for oxidant stabilization and enhanced mobility in heterogeneous settings with low permeability zones, 2) use of direct push technology for targeted high resolution delivery of oxidants and amendments, and 3) use of monitoring and sensing methods for direct feed back for process control and evaluation of remediation effectiveness.

This presentation will highlight advances in groundwater remediation based on more effective in situ delivery of oxidants and amendments to remediate a TTZ and achieve cleanup goals that help protect groundwater and associated drinking water resources.
\end{abstract}

Invited presentation at the NATO Advanced Research Workshop on "Drinking Water Protection by Integrated Management of Contaminated Land”, 21-23 March 2011, Belgrade, Serbia. 